Article

\title{
An Evaluation of Sporicidal Treatments against Blown Pack Spoilage Associated Clostridium estertheticum and Clostridium gasigenes Spores
}

\author{
Eden Esteves ${ }^{1}$, Leonard Koolman ${ }^{1}$, Paul Whyte ${ }^{2}$, Tanushree B. Gupta ${ }^{3}$ and Declan Bolton ${ }^{1, *(D)}$ \\ 1 Department of Food Safety, Teagasc Food Research Centre, Ashtown, D15 DY05 Dublin, Ireland; \\ edenesteves@ymail.com (E.E.); leonardkoolman87@gmail.com (L.K.) \\ 2 Herd Health Unit, School of Veterinary Medicine, University College Dublin, Belfield, \\ D04 V1W8 Dublin, Ireland; paul.whyte@ucd.ie \\ 3 Food Assurance Team, Hopkirk Research Institute, AgResearch Ltd., Massey University, \\ Palmerston North 4472, New Zealand; tanushree.gupta@agresearch.co.nz \\ * Correspondence: declan.bolton@teagasc.ie; Tel.: +353-(0)1-805-9539
}

Citation: Esteves, E.; Koolman, L.; Whyte, P.; Gupta, T.B.; Bolton, D. An Evaluation of Sporicidal Treatments against Blown Pack Spoilage Associated Clostridium estertheticum and Clostridium gasigenes Spores. Appl. Sci. 2022, 12, 1663. https:// doi.org/10.3390/app12031663

Academic Editor: Akikazu Sakudo

Received: 22 December 2021

Accepted: 3 February 2022

Published: 5 February 2022

Publisher's Note: MDPI stays neutral with regard to jurisdictional claims in published maps and institutional affiliations.

Copyright: (C) 2022 by the authors. Licensee MDPI, Basel, Switzerland. This article is an open access article distributed under the terms and conditions of the Creative Commons Attribution (CC BY) license (https:// creativecommons.org/licenses/by/ $4.0 /)$.

\begin{abstract}
Blown pack spoilage (BPS) occurs when meat is cross-contaminated with Clostridium estertheticum or Clostridium gasigenes spores, often from the meat processing environment. This study tested the efficacy of four sporicidal disinfectants commonly used in beef processing plants against C. estertheticum and C. gasigenes spores in a suspension test. D-values were obtained under model 'clean' (sterile distilled water, SDW) and 'dirty' (3 g/L bovine serum albumin, BSA) conditions. Mean concentration $\left(\log _{10} \mathrm{CFU} / \mathrm{mL}\right.$ ) were calculated from direct counts. The levels of dipicolinic acid (DPA), indicating damage to the core of these spores, was also monitored using a terbium ( $\mathrm{Tb}$ )-DPA assay for treatment 1 (peracetic acid as the active ingredient) in SDW and BSA. In SDW sporicidal treatment 3 (containing peroxymonosulphate) was the most effective against $C$. estertheticum spores but under 'dirty' (BSA) conditions sporicidal treatments 1 and 2 were more effective. A similar pattern was obtained with $C$. gasigenes with treatment 3 being the most effective in SDW but treatment 2 (sodium hypochlorite as the active ingredient) being more effective in BSA. The lower DPA concentrations obtained in SDW versus BSA demonstrated the protective effect of organic matter. It was concluded that meat processors should use a 5\% formulation containing sodium hypochlorite, sodium hydroxide and alkylamine oxide to eliminate BPS Clostridial spores in the abattoir.
\end{abstract}

Keywords: blown pack spoilage; sporicidal agents; Clostridium estertheticum; Clostridium gasigenes; spores

\section{Introduction}

Blown pack spoilage (BPS) typically occurs in chilled vacuum packaged red meat and is characterized by a foul cheese-like odor, accumulation of drip, and copious amounts of gas (primarily carbon dioxide, $\mathrm{CO}_{2}$ ) in correctly stored packs [1-3]. Psychrophilic and psychrotrophic Clostridium estertheticum and Clostridium gasigenes are the main causative agents of BPS. Spores from these Clostridium spp. are ubiquitous in the abattoir environment and have been isolated from stockyard pens, slaughter floors, the processing environment, lairage, evisceration table, conveyor belts, packaging machines and bleeding area and can cross-contaminate carcasses during slaughter and dressing [4-8]. Control is reliant on eliminating these spores from the abattoir environment.

Bacterial spores are highly resistant to chemical and physical agents [9] and there is currently no standardized method for inactivating BPS spores in the meat plant environment [10-13]. Chemical agents such as glutaraldehyde, formaldehyde, iodine compounds, chlorine compounds, hydrogen peroxide $\left(\mathrm{H}_{2} \mathrm{O}_{2}\right)$, peroxy acids, ethylene oxide and betapropiolactone have sporicidal activity [14]. Oxidizing agents are widely used including peracetic acid (PAA) and $\mathrm{H}_{2} \mathrm{O}_{2}$ based sanitizers, which can be applied individually or in 
combination taking advantage of any synergistic effect [15-17]. PAA based chemical agents inactivate bacteria, fungi and yeasts [18-20] and bacterial spores using exposure times ranging from $15 \mathrm{~s}$ to $30 \mathrm{~min}$ and concentrations of between 0.02 to $1 \%$ [21]. These products have been effectively applied against spores of Clostridioides difficile, Clostridium sporogenes, Bacillus megaterium, Bacillus amiloliquefaciens and Geobacillus theromophillus [22-24] and have the added advantage of removing biofilms produced by Listeria monocytogenes [25-27].

Beside the application of peryoxygens, such as peroxyacetic acid (PAA) combined with $\mathrm{H}_{2} \mathrm{O}_{2}$, non-PAA based chemicals have also been used. Chlorine has been widely used as a disinfectant against bacterial spores [14]. Sodium hypochlorite $(\mathrm{NaOCl})$ is the preferred form of chlorine releasing agent. In the presence of sodium hydroxide $(\mathrm{NaOH})$, sodium hypochlorite is a strong basic disinfectant. It provides stabilized hypochlorite ions $\left(\mathrm{OCl}^{-}\right)$which mediates cellular damage via hydroxide ions $\left(\mathrm{OH}^{-}\right)$by directly or indirectly interacting with proteins, polysaccharides and fats. Hydroxide ions can also dissolve organic materials. Moreover, the presence of sodium hydroxide reduces the corrosive effects of hypochlorite ions. Stabilized and concentrated sodium hypochlorite is therefore recommended for cleaning operations [28]. Chlorine based disinfectants such as sodium hypochlorite have been continually improved for the environmental control of $C$. difficile spores [29]. Sodium hypochlorite has also shown inactivation properties against Bacillus anthracis spores alongside other oxidizing agents [30].

Although peryoxygens and chlorine releasing agents are ideally preferred for sporicidal activity, some alternatives such as potassium peroxymonosulphate and alcohols may also be used for decontamination and disinfection purposes. Potassium peroxymonosulphate provides reactive halogen species (HOX) causing cell membrane damage and leakage of intracellular materials evidenced by changes in cell morphology [31,32]. Peroxymonosulphate based disinfectants have previously reduced levels of Pseudomonas aeruginosa and Salmonella enterica in animal holding environments, and inactivated chlorine-resistant bacterial spores in combination with UV irradiation [32,33]. Alcohol application has been reported to inhibit L-alanine triggered germination of Bacillus subtilis spores by interacting with L-alanine receptor sites on the spore [14]. Application of ethanol in combination with heating, alkalinization, and acidification induces effective sporicidal activity against C. difficile, Bacillus thuringiensis and B. subtilis [34].

There is a need to eliminate BPS Clostridium spores from the abattoir environment to protect against cross-contamination of carcasses, primal cuts and BPS during vacuum packaged storage. The objective of this study was therefore to test the efficacy of four commonly used sporicidal agents in a suspension test against $C$. estertheticum and C. gasigenes spores, in clean (sterile distilled water, SDW) and dirty ( $3 \mathrm{~g} / \mathrm{L}$ bovine serum albumin, BSA) medium conditions.

\section{Materials and Methods}

\subsection{Bacterial Strains and Preparation of Spore Inoculum}

Type strains Clostridium estertheticum subsp. estertheticum (DSMZ 8809) and Clostridium gasigenes (DSMZ 12272) were purchased from Deutsche Sammlung von Mikroorganismen und Zellkulturen GmbH (DSMZ, Braunschweig, Germany). The reference strains were cultured anaerobically in pre-reduced peptone yeast extract glucose starch (PYGS) broth and stored at $4{ }^{\circ} \mathrm{C}$ until sporulation (approximately three months). Prior to inoculation all sterilized media were cooled and stored inside an anaerobic cabinet (Don Whitley Scientific Ltd., Shipley, UK), under an atmosphere of mixed gas $\left(\mathrm{CO}_{2}\right.$ and $\left.\mathrm{N}_{2}\right)$ at $37^{\circ} \mathrm{C}$ and used within $48 \mathrm{~h}$. Spores were harvested using the method previously described [35]. Briefly, spore suspensions were recovered by centrifugation $\left(7500 \times g, 4{ }^{\circ} \mathrm{C}, 10 \mathrm{~min}\right)$ and washed with saline $(0.85 \% \mathrm{NaCl})$ (Sigma Aldrich, Arklow, Co. Wicklow, Ireland) three times. The washed spore suspension was then sonicated ( $40 \mathrm{kHz}$ for $15 \mathrm{~min}$ ) in an ultrasonic water bath (VWR International, Chicago, IL, USA) at room temperature. Sonication/centrifugation/wash cycles were repeated three times. The spores were then suspended in $10 \mathrm{~mL}$ saline and stored at $-20^{\circ} \mathrm{C}$. Final spore numbers were enumerated by preparing serial dilutions of 
the heat treated $\left(80^{\circ} \mathrm{C}, 10 \mathrm{~min}\right)$ spore suspensions in saline and plating out $0.1 \mathrm{~mL}$ aliquots on CBA supplemented with 5\% defibrinated horse blood and incubating anaerobically for three weeks at $4{ }^{\circ} \mathrm{C}$.

\subsection{Sporicidal Treatments}

The four commercial disinfectants tested in these studies, chemical formulation and the concentrations used are provided in Table 1. The chemical compositions were obtained from the relevant material safety data sheet (MSDS). In addition, it is recognized that the active content will vary from batch to batch depending on manufacture and as a result of sampling or analytical errors. All concentrations listed below are industrially recommended for use in beef processing lines. Solutions of each agent were prepared as recommended by the manufacturer to the required concentration. All disinfectants are numerically listed as the suppliers have not permitted the use of product names.

Table 1. The sporicidal product formulations and concentrations used in this study.

\begin{tabular}{ccc}
\hline $\begin{array}{c}\text { Disinfectant/ } \\
\text { Treatment }\end{array}$ & Chemical Composition & $\begin{array}{c}\text { Recommended } \\
\text { Concentration }\end{array}$ \\
\hline 1 & Hydrogen Peroxide (10-30\%), Acetic acid (1-10\%), \\
Peracetic acid (1-10\%) & $10 \%$ \\
\hline 2 & $\begin{array}{c}\text { Sodium hypochlorite (5.2-10\%), Sodium hydroxide } \\
(5-10 \%), \text { Alkylamine oxide (3-5\%) }\end{array}$ & $5 \%$ \\
\hline 3 & Peroxymonosulphate (30-50\%), Sulphamic Acid (1-10\%), \\
Troclosene Sodium (1-10\%) & $4 \%$ \\
\hline 4 & $\begin{array}{c}\text { Alcohols, C9-11, Ethoxylate (10-30\%), Orthophosphoric } \\
\text { acid (10-30\%), Sulphuric acid (1-10\%), Iodine (1-10\%) }\end{array}$ & $2 \%$ \\
\hline
\end{tabular}

\subsection{Suspension Test}

Each Clostridium spp. was used as a single strain to establish individual inactivation profiles for both C. estertheticum and C. gasigenes. The suspension testing procedure was based on BS EN 13704:2018 "Chemical disinfectants-Quantitative suspension test for evaluation of sporicidal activity of chemical disinfectants used in food, industrial, domestic and institutional areas-Test method and requirements (phase 2, step 1)" which describes the use of suspension tests when evaluating the efficacy of chemical agents against bacterial spores and recommends the use of one test organism per suspension with a well-defined sporulation behavior.

Sporicidal solutions were prepared in $30 \mathrm{~mL}$ polystyrene tubes the day before conducting the experiments by adding double strength $10 \% v / v$ treatment $1, \% v / v$ treatment 2 , $4 \% w / v$ treatment 3 and $2 \% v / v$ treatment 4 to SDW to make up a final volume of $10 \mathrm{~mL}$. The sporicidal products were then placed in a $25{ }^{\circ} \mathrm{C}$ incubator to equilibrate overnight. Depending on the final concentration of spores, approximately $10^{5} \mathrm{CFU} / \mathrm{mL}$ spore suspensions were prepared by diluting in sterile distilled water (SDW). If the final spore concentration was lower than $10^{5} \mathrm{CFU} / \mathrm{mL}$, aliquots of spore suspensions were added together and centrifuged at $7500 \times g$ for $10 \mathrm{~min}$. The resultant pellet was resuspended in SDW and made up to $10 \mathrm{~mL}$ suspensions of approximately $10^{5} \mathrm{CFU} / \mathrm{mL}$. Spore suspensions were thoroughly vortexed before use to ensure homogeneity and a small volume $(10 \mathrm{~mL})$ was transferred to tubes containing each sporicidal treatment $(10 \mathrm{~mL})$ making a final volume of $20 \mathrm{~mL}$. Based on the preliminary data for these treatments the following contact times (t) $0,10,20,30,40,50$, and 60 min were used to calculate D-values. At each sampling time, $10 \mathrm{~mL}$ Dey-Engley's neutralising broth (D3435; Sigma Aldrich, Arklow, Co. Wicklow, Ireland) was added to each tube for $15 \mathrm{~min}$ to stop further reaction between spores and the respective sporicidal agents. This was followed by centrifugation at $7500 \times g$ $10 \mathrm{~min}$. The supernatant was removed and the pellet was resuspended in $3 \mathrm{~mL} \mathrm{SDW}$. 
This procedure was then repeated in a bovine serum albumin (BSA) solution to mimic "dirty conditions" as recommended by the British Standards Institution (BSI) (EN 13704:2018). Exactly, $3 \mathrm{~g} / \mathrm{L}$ of BSA was made up in SDW and sterilized by membrane filtration (0.22 $\mu \mathrm{m}$ pore size) using vacuum (Millipore, Merck, Cork, Ireland). The contact times $(\mathrm{t})$ used were also as for SDW.

Surviving spore suspensions were serially diluted in maximum recovery diluent (MRD; Sigma Aldrich 07233) and plated out in duplicate on Columbia blood agar (CBA; Sigma Aldrich 27688) and incubated anaerobically at $4{ }^{\circ} \mathrm{C}$ for three weeks. Thereafter, presumptive surviving $C$. estertheticum and C. gasigenes were counted and confirmed by performing quantitative real time PCR (qPCR) as described by [36].

\subsection{Determination of Dipicolinic acid (DPA) Release from Spores}

DPA levels were monitored for sporicidal treatment 1 in SDW and BSA to demonstrate the protective effect of organic matter. DPA is associated with stress resistance in bacterial spores [37]. The release of DPA from the spore core and the subsequent formation of a Terbium (Tb)-DPA complex is indicative of sporicidal activity. This study used the method published by [38]. Briefly, solutions of DPA (499-83-2, Sigma Aldrich, Arklow, Co., Wicklow, Ireland) at a concentration of $0.5,0.75,1,1.25,2.5,3,4.5$, and $5 \mu \mathrm{M}$ in water $\left(\mathrm{dH}_{2} \mathrm{O}\right)$ and $200 \mathrm{nM}$ terbium (III) chloride $\left(\mathrm{TbCl}_{3} ; 451304\right.$, Sigma Aldrich, Arklow, Co., Wicklow, Ireland) in Tris- $\mathrm{HCl}$ buffer $(20 \mathrm{mM}$, pH 7.5) was sterilised by membrane filtration (Merck Millipore, Ireland). In a 96 well microplate (Costar 96 well, black microplates; Corning Incorporated, Product Ref 3916), $150 \mu \mathrm{L}$ of $\mathrm{TbCl}_{3}$ was mixed with $50 \mu \mathrm{L}$ of each concentration of DPA solution. A microplate reader (Tecan, Spark Control V. 30) was used to record the fluorescence of the Tb-DPA complex with excitation set at $280 \mathrm{~nm}$, emission at $545 \mathrm{~nm}$, a delay time of $50 \mu \mathrm{s}$, an interval of $1200 \mu \mathrm{s}$ and gain value set at 1279. The relative fluorescence units (RFU) was plotted against the concentrations of DPA to generate a standard curve. The RFU values and standard curve were used to derive a regression equation to calculate DPA released from each sample. After treatment at the different contact times, the treatment suspensions were centrifuged at $7500 \times g$ for $10 \mathrm{~min}$ and the supernatant was retained. Exactly, $50 \mu \mathrm{L}$ of the collected supernatants were mixed with $150 \mu \mathrm{L} \mathrm{TbCl}_{3}$ solution in a 96 well microplate (Costar 96 well, black microplates; Corning Incorporated, Ref 3916). A microplate reader (Tecan, Spark Control V. 30) was used to determine the fluorescence of DPA-Tb complex. Corrected RFU values were obtained by subtracting the RFU of treated spores from the untreated control. Total DPA content was estimated by using corrected RFU and line equation derived from the standard curve above.

\subsection{Statistical Analysis}

Each sporicidal treatment was applied to BPS spores in duplicate on three different occasions. The D-value (decimal reduction time defined as the time to achieve a $90 \%$ or $1 \mathrm{log}$ reduction) were calculated from the inverse of the slope $(-1 /$ slope). The unpaired Welch's $t$ test was performed to compare the effect of each treatment against a spore control group to determine if there were significant reductions in spore concentration. Similar test was used to compare the D-values obtained with SDW v BSA for a given organism and treatment. A two-way analysis of variance (ANOVA) followed by Tukey's post hoc test was performed to determine if there were significant difference between treatments keeping the organism and solution (SDW or BSA) constant. All tests were carried out in GraphPad Prism v7.02 (Graphpad Software Inc., San Diego, CA, USA).

\section{Results}

Using $10 \% v / v$ treatment 1 under clean conditions, reductions of $2.9 \log _{10} \mathrm{CFU} / \mathrm{mL}$ after 50 min were recorded for $C$. estertheticum spores, after which no colonies were detected, compared to the spore control group which averaged $4.6 \log _{10} \mathrm{CFU} / \mathrm{mL}$ for $60 \mathrm{~min}$ $(p<0.0001)$ (Figure 1A). Susceptibility of spores to $10 \% v / v$ treatment 1 was also tested in 
'dirty conditions' using $3 \mathrm{~g} \mathrm{~L}^{-1}$ BSA, where spore counts were significantly reduced by $4.1 \log _{10} \mathrm{CFU} / \mathrm{mL}$ after $60 \mathrm{~min}$ (Figure 1B), in comparison to the control group (4.5 $\log _{10}$ $\mathrm{CFU} / \mathrm{mL} ; p<0.05)$. In SDW, C. gasigenes spores were reduced by $3.2 \log _{10} \mathrm{CFU} / \mathrm{mL}$ after $60 \mathrm{~min}$ (Figure 1C), in comparison to the spore control group $\left(4.5 \log _{10} \mathrm{CFU} / \mathrm{mL}\right)(p<0.01)$. For treatment 1 in BSA, C. gasigenes spores were reduced by $2.7 \log _{10} \mathrm{CFU} / \mathrm{mL}$ at $60 \mathrm{~min}$, in comparison to the controls $\left(4.3 \log _{10} \mathrm{CFU} / \mathrm{mL} ; p<0.05\right)$ (Figure 1D).
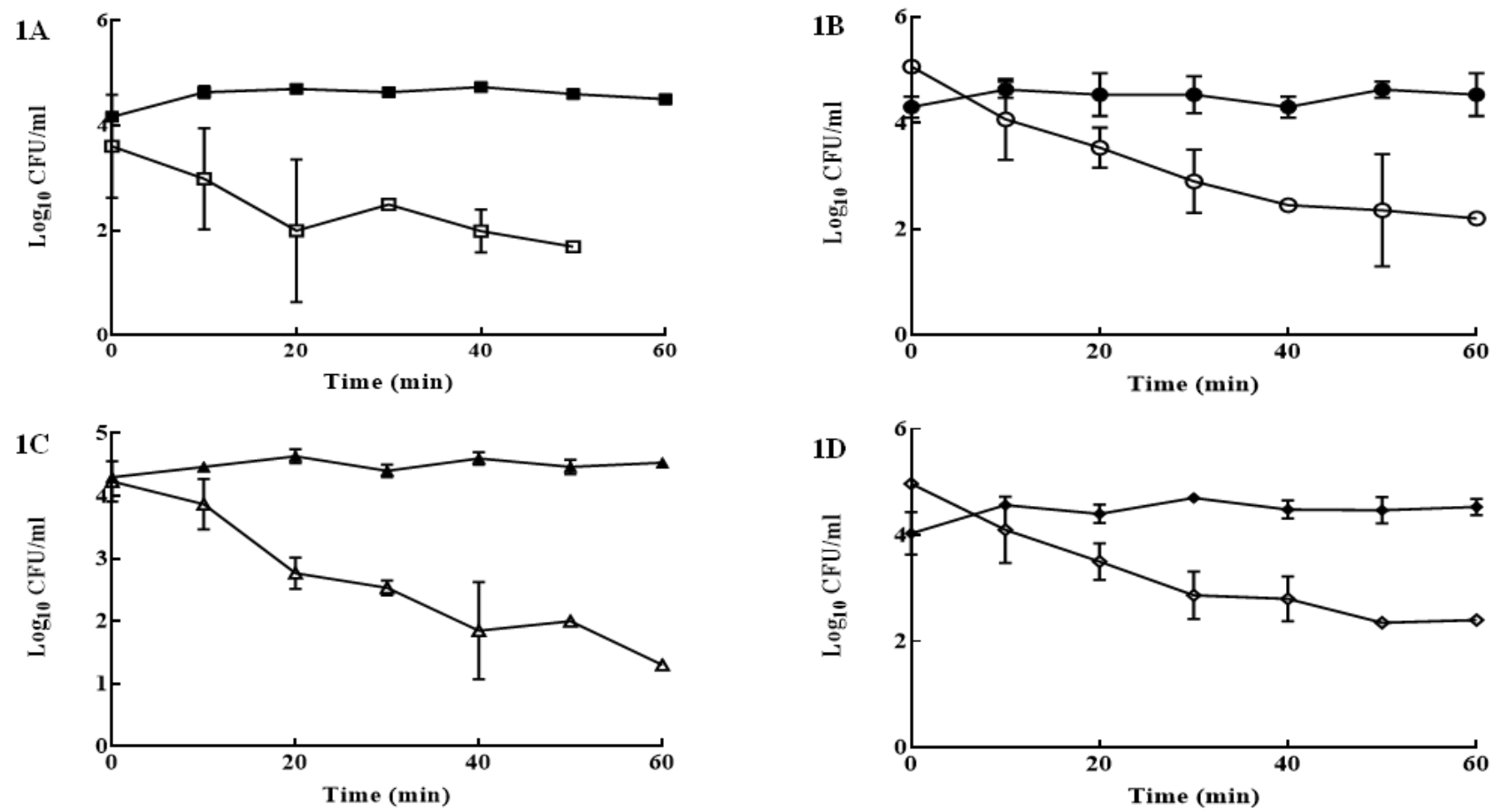

Figure 1. Sporicidal effect of $10 \% v / v$ treatment 1 at $0,10,20,30,40,50$ and 60 min contact times for

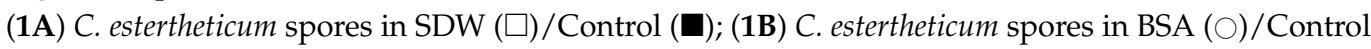
$(\bullet)$; (1C) C. gasigenes spores in SDW $(\triangle) /$ Control $(\boldsymbol{\Delta})$; (1D) C. gasigenes spores in BSA $(\diamond) /$ Control $(\diamond)$.

Treatment $2(5 \% v / v)$ in SDW gradually reduced C. estertheticum spores from $3.2(\mathrm{~T} 0)$ to $2 \log _{10} \mathrm{CFU} / \mathrm{mL}(\mathrm{t}=60)$ (Figure 2A), compared to the controls $\left(4.3 \log _{10} \mathrm{CFU} / \mathrm{mL}\right.$; $p<0.001)$. In BSA, the same treatment reduced C. estertheticum by $2.1 \log _{10} \mathrm{CFU} / \mathrm{mL}$ from after $60 \mathrm{~min}$ (Figure 2C) compared to the controls $\left(4.5 \log _{10} \mathrm{CFU} / \mathrm{mL} ; p<0.01\right)$. Using $5 \%$ $v / v$ treatment 2 in SDW reduced C. gasigenes by $1.8 \log _{10} \mathrm{CFU} / \mathrm{mL}$ with no growth observed at $t=60 \mathrm{~min}$ (Figure 2C). Statistically different results were obtained in BSA for the same treatment, where spores reduced by $2.7 \log _{10} \mathrm{CFU} / \mathrm{mL}$ (Figure 2D). Counts obtained for $C$. gasigenes control remained significantly higher at $4.6 \log _{10} \mathrm{CFU} / \mathrm{mL}(p<0.01)$.

For $4 \% w / v$ treatment 3 in SDW, C. estertheticum spores were reduced by $3.3 \log _{10}$ $\mathrm{CFU} / \mathrm{mL}$ after $40 \mathrm{~min}$ after which no growth was observed compared to spore controls (3.6 $\log _{10} \mathrm{CFU} / \mathrm{mL} ; p<0.01$ ) (Figure 3A). For the same treatment in BSA, C. estertheticum spores were reduced by $2.1 \log _{10} \mathrm{CFU} / \mathrm{mL}$ at $60 \mathrm{~min}$ compared to controls (4.3 $\log _{10}$ $\mathrm{CFU} / \mathrm{mL} ; p<0.01$ ) (Figure $3 \mathrm{~B}$ ). For $4 \% w / v$ treatment 3 in SDW, counts were reduced by $1.9 \log _{10} \mathrm{CFU} / \mathrm{mL}$ with no growth observed after $40 \mathrm{~min}$, in comparison to $C$. gasigenes control $\left(3.4 \log _{10} \mathrm{CFU} / \mathrm{mL}\right)(p<0.01)$ (Figure 3C). The same treatment in BSA showed reductions of $2 \log _{10} \mathrm{CFU} / \mathrm{mL}$ by $60 \mathrm{~min}$, compared to the control $\left(4.4 \log _{10} \mathrm{CFU} / \mathrm{mL}\right)$ $(p<0.01)$ (Figure 3D). 

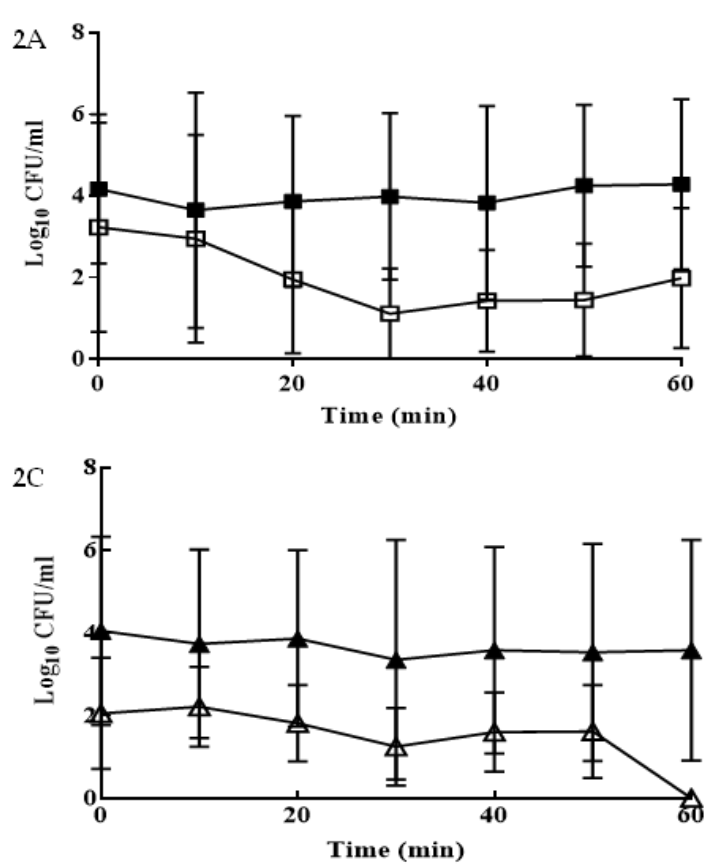
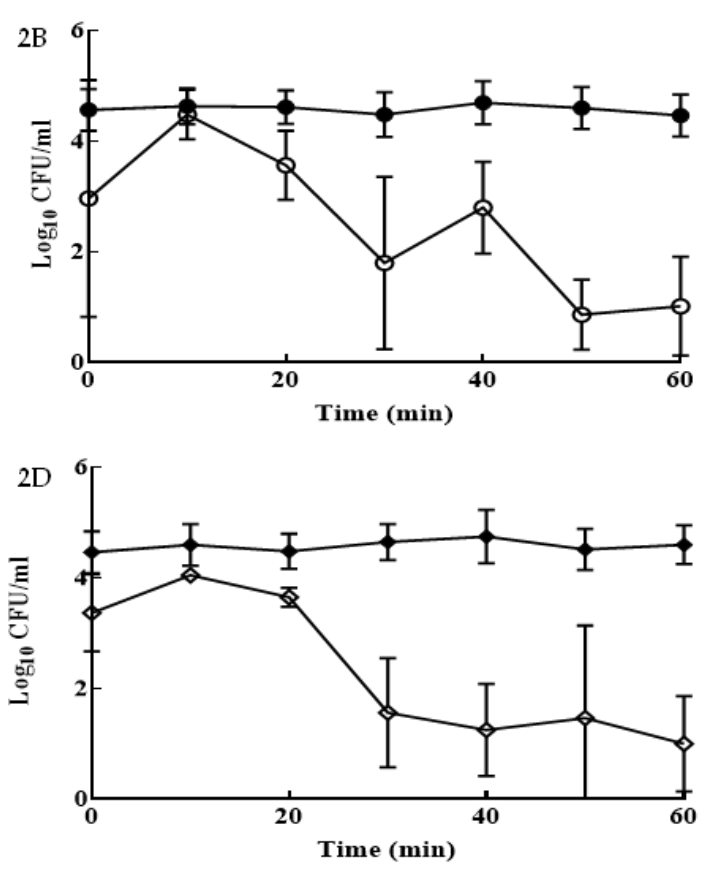

Figure 2. Sporicidal effect of $5 \% v / v$ treatment 2 at 0, 10, 20, 30, 40, 50 and 60 min contact times for (2A) C. estertheticum spores in SDW ( $\square$ )/Control ( $\square)$; (2B) C. estertheticum spores in BSA ( $\bigcirc) /$ Control $(\bullet)$; (2C) C. gasigenes spores in SDW $(\triangle) /$ Control ( $\mathbf{\Delta})$; (2D) C. gasigenes spores in BSA $(\diamond) /$ Control $(\diamond)$.
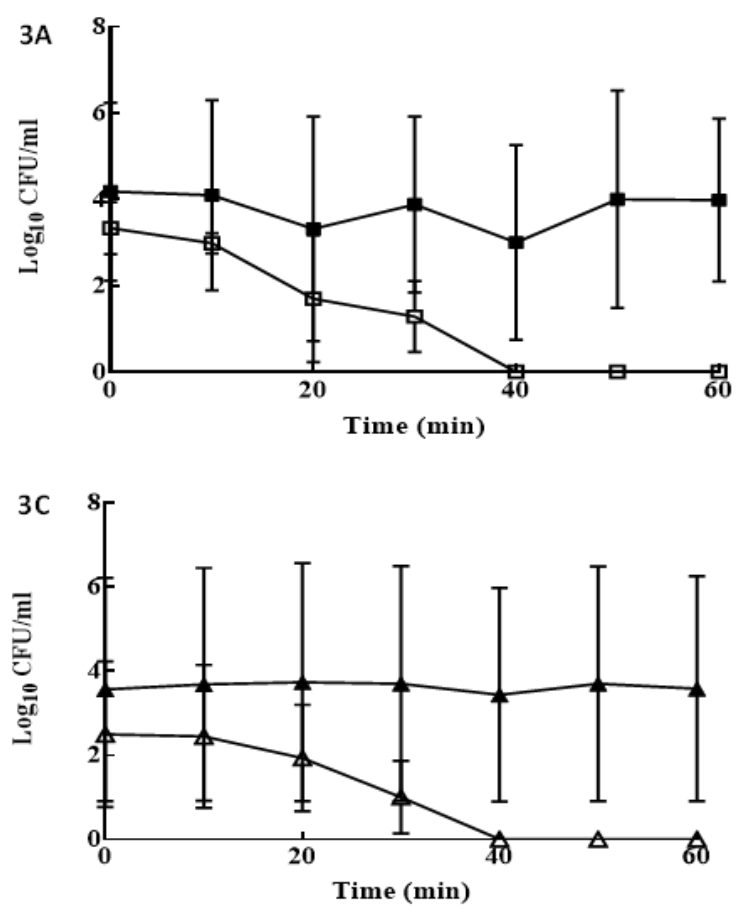
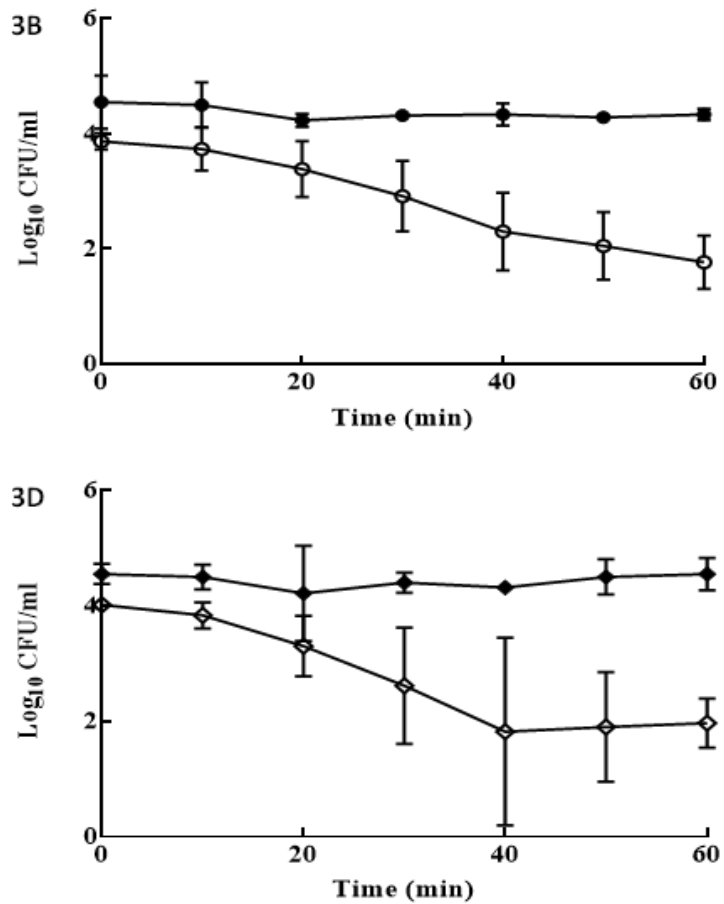

Figure 3. Sporicidal effect of $4 \% w / v$ treatment 3 at $0,10,20,30,40,50$, and 60 min contact times for (3A) C. estertheticum spores in SDW ( $\square$ )/Control ( $\square$ ); (3B) C. estertheticum spores in BSA $(\bigcirc) /$ Control $(\bullet)$; (3C) C. gasigenes spores in SDW $(\triangle) /$ Control $(\boldsymbol{\Delta})$; (3D) C. gasigenes spores in BSA $(\diamond) /$ Control $(\diamond)$.

In SDW, $2 \% v / v$ treatment 4 reduced C. estertheticum spore counts by $2.2 \log _{10} \mathrm{CFU} / \mathrm{mL}$ after $50 \mathrm{~min}$ with no further counts at $60 \mathrm{~min}$, compared to controls $\left(4.7 \log _{10} \mathrm{CFU} / \mathrm{mL}\right.$; $p<0.0001$ ) (Figure 4A). In BSA, lower reduction of $1.6 \log _{10} \mathrm{CFU} / \mathrm{mL}$ (Figure $4 \mathrm{~B}$ ) were obtained by 60 min compared to the controls $\left(4.5 \log _{10} \mathrm{CFU} / \mathrm{mL} ; p<0.0001\right)$. In SDW, $2 \% v / v$ treatment 4 showed a gradual reduction of $C$. gasigenes by $2.1 \log _{10} \mathrm{CFU} / \mathrm{mL}$ at 
T50 and no growth observed at T60, whereas concentrations as high as $4.5 \log _{10} \mathrm{CFU} / \mathrm{mL}$ were recorded in the control group $(p<0.0001)$ (Figure 4C). In BSA, treatment with $2 \% v / v$ treatment 4 reduced spore counts by $1.7 \log _{10} \mathrm{CFU} / \mathrm{mL}$, in comparison to the $C$. gasigenes control group $\left(4.8 \log _{10} \mathrm{CFU} / \mathrm{mL}\right)(p<0.01)$ (Figure $\left.4 \mathrm{D}\right)$.
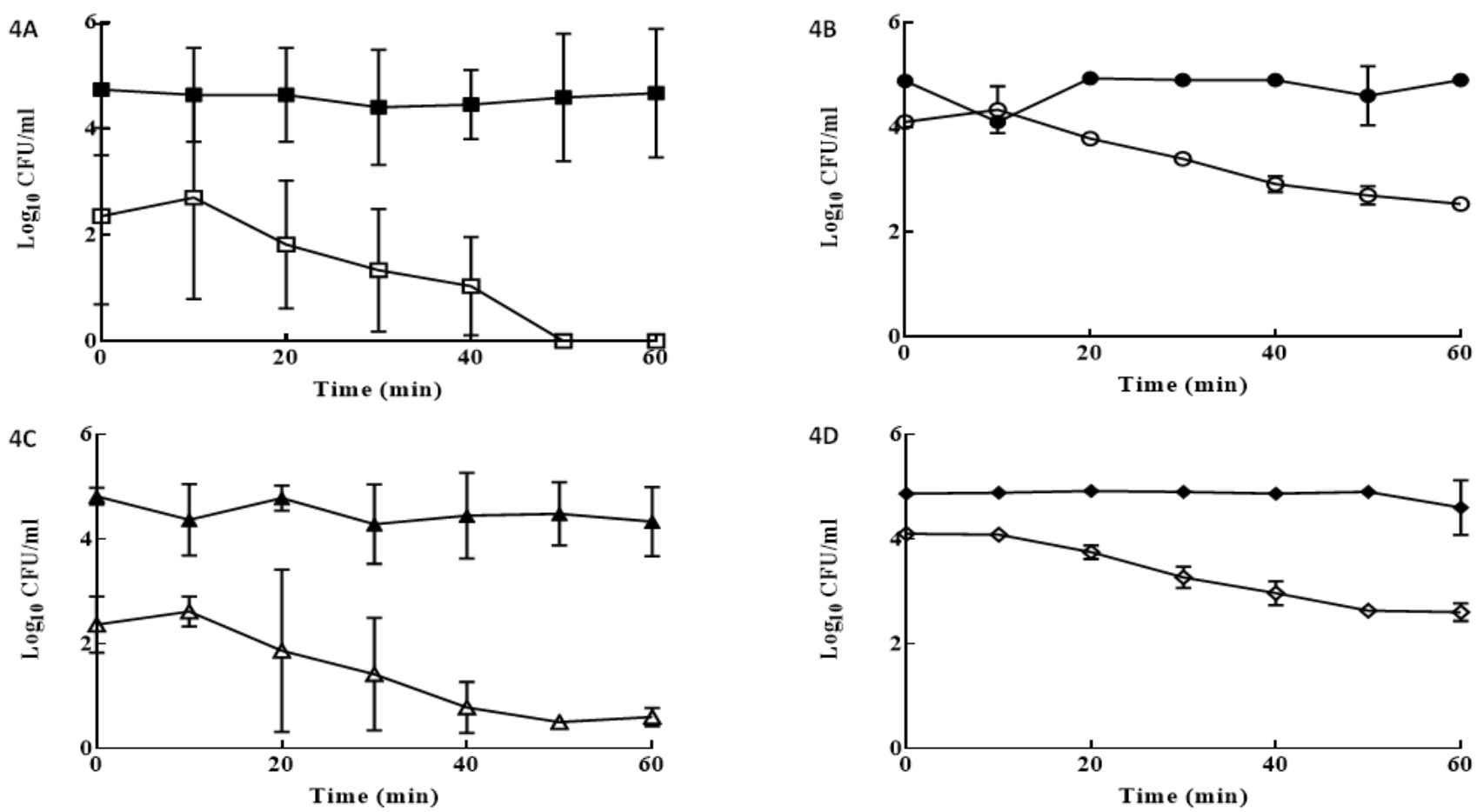

Figure 4. Sporicidal effect of $2 \% v / v$ treatment 4 at $0,10,20,30,40,50$, and 60 min contact times for (4A) C. estertheticum spores in SDW ( $\square$ )/Control ( $\square)$; (4B) C. estertheticum spores in BSA ( $\bigcirc) /$ Control $(\bullet)$; (4C) C. gasigenes spores in SDW $(\triangle) /$ Control ( $\mathbf{\Delta})$; (4D) C. gasigenes spores in BSA $(\diamond) /$ Control $(\diamond)$.

The D-values for C. estertheticum ranged from 12.7 to $39.4 \mathrm{~min}$ in SDW and from 18.5 to $33.3 \mathrm{~min}$ in BSA (Table 2). For all four sporicidal agents the D-value was significantly $(p<0.05)$ lower in SDW. In this medium, $4 \% w / v$ treatment 3 was the most effective with a D-value (12.7 $\mathrm{min}$ ) that was significantly lower than the D-values for $10 \% v / v$ treatment 1 $(26.8 \mathrm{~min})$ and $2 \% v / v$ treatment $4(23.3 \mathrm{~min})$ which were, in turn, significantly lower than $5 \% v / v$ treatment $2(39.4 \mathrm{~min})(p<0.05)$. In BSA the D-values obtained for $1(20.0 \mathrm{~min})$ and 2 (18.5 $\mathrm{min})$ were statistically similar and significantly lower than treatment $3(25.9 \mathrm{~min})$ which was significantly lower than treatment 4 (33.3 $\mathrm{min})$. Thus, overall in the absence of organic matter sporicidal agent 3 was the most effective but under 'dirty' conditions sporicidal treatments 1 and 2 were more effective at reducing C. estertheticum spores.

In contrast, treatment 2 was the least effective against $C$. gasigenes spores in SDW with a D-value of $30.4 \mathrm{~min}$ which was significantly higher than treatments 1 (20.5 $\mathrm{min}$ ) and 4 (19.9 min) which were, in turn, significantly higher than treatment 3 (16.1 min) $(p<0.05)$. In BSA the lowest D-value was obtained with treatment 2 ( $17.1 \mathrm{~min})$ followed by 1 (22.6 $\mathrm{min})$ and 3 (24.8 $\mathrm{min}$ ) which were significantly higher than treatment 2 but significantly lower that treatment $4(31.5 \mathrm{~min})(p<0.05)$. In summary, sporicidal treatment 3 was the most effective against C. estertheticum spores in SDW but treatment 2 was more effective in BSA.

The increase in the concentration of DPA as it was released from the coat of C. estertheticum and C. gasigenes spores during treatment with sporicidal treatment 1 in SDW and BSA is shown in Figure 5. A steady increase was observed with higher concentrations obtained in SDW demonstrating the protective effect of the organic matter when BSA was added to the solution. 
Table 2. The D-values for C. estertheticum and C. gasigenes treated with the different sporicidal products.

\begin{tabular}{|c|c|c|c|}
\hline Sporicidal Product & Treatment Conditions & D-Value (Minutes) & $\mathrm{SE}^{1}$ \\
\hline \multicolumn{4}{|c|}{ Clostridium estertheticum } \\
\hline \multirow{2}{*}{1} & SDW & $26.8^{\mathrm{A} / \mathrm{B}}$ & 0.009 \\
\hline & BSA & $20.0^{\mathrm{B} / \mathrm{A}}$ & 0.006 \\
\hline \multirow{2}{*}{2} & SDW & $39.4^{\mathrm{A} / \mathrm{C}}$ & 0.012 \\
\hline & BSA & $18.5^{\mathrm{B} / \mathrm{A}}$ & 0.018 \\
\hline \multirow{2}{*}{3} & SDW & $12.7^{\mathrm{A} / \mathrm{A}}$ & 0.009 \\
\hline & BSA & $25.9^{\mathrm{B} / \mathrm{B}}$ & 0.003 \\
\hline \multirow{2}{*}{4} & SDW & $23.3^{\mathrm{A} / \mathrm{B}}$ & 0.006 \\
\hline & BSA & $33.3^{B / C}$ & 0.004 \\
\hline \multicolumn{4}{|c|}{ Clostridium gasigenes } \\
\hline \multirow{2}{*}{1} & SDW & $20.5^{\mathrm{A} / \mathrm{B}}$ & 0.006 \\
\hline & BSA & $22.6^{\mathrm{B} / \mathrm{B}}$ & 0.006 \\
\hline \multirow{2}{*}{2} & SDW & $30.4^{\mathrm{A} / \mathrm{C}}$ & 0.009 \\
\hline & BSA & $17.1^{\mathrm{B} / \mathrm{A}}$ & 0.013 \\
\hline \multirow{2}{*}{3} & SDW & $16.1^{\mathrm{A} / \mathrm{A}}$ & 0.007 \\
\hline & BSA & $24.8^{\mathrm{B} / \mathrm{B}}$ & 0.006 \\
\hline \multirow{2}{*}{4} & SDW & $19.9^{\mathrm{A} / \mathrm{B}}$ & 0.007 \\
\hline & BSA & $31.5^{\mathrm{B} / \mathrm{C}}$ & 0.003 \\
\hline
\end{tabular}

A/A First letter (A/A) denotes statistical differences observed between sporicidal products in SDW and BSA for a given target bacteria. The second letter (A/ $\underline{\mathrm{A}}$ ) denotes statistically significant differences between the sporicidal treatments with the bacterium and solution (SDW and BSA) being held constant. Statistical differences were analyzed at the $5 \%$ level $(p<0.05) .{ }^{1} \mathrm{SE}$, standard error.

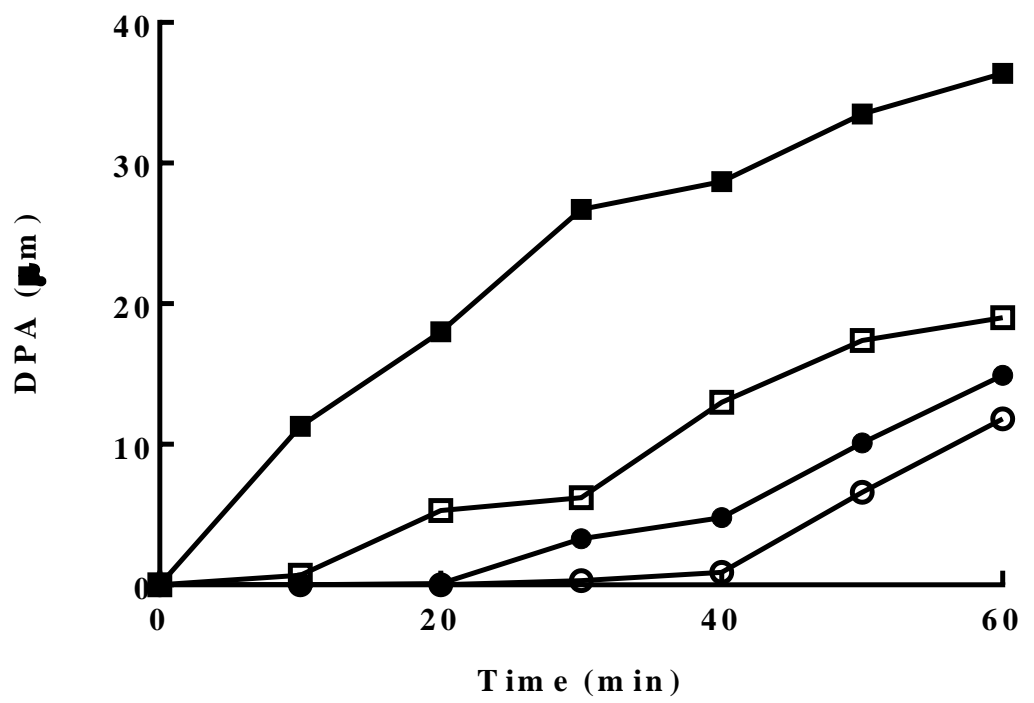

Figure 5. The concentration of DPA $(\mu \mathrm{m})$ released from the spores of C. estertheticum in SDW $(\mathbf{\square})$, C. gasigenes in SDW $(\square)$, C. estertheticum in BSA $(\bullet)$, C. gasigenes in BSA $(\bigcirc)$ during treatment with sporicidal product 1 .

\section{Discussion}

C. estertheticum and C. gasigenes spores are commonly found in the meat processing environment $[6,12,39]$ with inevitable cross-contamination of carcasses and primal cuts [40]. 
This study investigated the efficacy of four sporicidal formulations in eliminating C. estertheticum and C. gasigenes spores in clean (SDW) and dirty (BSA) conditions in suspension tests. In SDW all treatments were equally effective.

Treatment 1 was a mixture of hydrogen peroxide, acetic acid, and peracetic acid. Hydrogen peroxide is a strong oxidizing agent and more active in the presence of acetic acid. Peracetic acid decomposes to hydrogen peroxide and acetic acid and is more potent than hydrogen peroxide alone in the presence of organic matter [14]. A recent study has demonstrated sporicidal formulations containing hydrogen peroxide, peracetic acid and acetic acid are effective against $C$. sporogenes and $C$. difficile spores with D values as low as 2.1 and $5.3 \mathrm{~min}$, respectively [41]. This formulation has strong antimicrobial activity [17,21,42], including against Clostridial spores [42-45] and has been recommended for the control of BPS Clostridium spores [10,13].

Our data suggests that treatment 2, a mixture of sodium hypochlorite, sodium hydroxide and alkylamine oxide, was more effective against $C$. gasigenes spores when tested in BSA. Sodium hypochlorite is a strong basic disinfectant that inactivates Clostridium spores $[29,30]$. Sodium hydroxide enhances this activity and dissolves or precipitates organic matter thereby preventing any inhibition of the hypochlorite [46-49]. Hence, this formulation has been recommended for disinfecting food processing environments [28].

Treatment 3 (peroxymonosulphate, sulphamic acid and troclosene sodium) was not as effective as treatments 1 and 2. This was unexpected as previous studies have suggested that peroxymonosulphate, an oxidizing agent, has sporicidal activity $[17,41]$ even in the presence of moderate organic debris [50].

Treatment 4 (alcohols, ethoxylate, orthophosphoric acid, sulphuric acid and iodine) was the least effective sporicidal agent. Alcohols kill vegetative bacteria cells by protein denaturation [51,52] but not spores [6]. However, when ethoxylated they make useful detergents [53]. Sulphuric and orthophosphoric acid have been reported to kill Enterococcus faecalis, Salmonella and Streptococcus spp. but their sporicidal activity has not been demonstrated [54-56]. Iodine also kills vegetative bacterial cells [57] including in organic solutions [58] but requires other treatments such as UV to eliminate spores [59,60]. Furthermore, application of treatment 4 to $C$. gasigenes showed no sign of growth at T50 but colonies were recorded at T60. As a result, good hygienic practice (GHP) and clean in place (CIP) is very important to prevent the occurrence of BPS.

The sporicidal action of treatment 1 was demonstrated by the increasing concentrations of DPA over time, which is released when the spore coat is damaged during chemical treatment [61]. The slower release of DPA from the core of C. estertheticum and C. gasigenes spores in BSA as compared to SDW demonstrated the protective effect of organic matter. Other factors affecting DPA concentrations in sporicidal assays include spore hydration and dry matter $[37,62,63]$.

\section{Conclusions}

This study reported the efficacy of four commonly used sporicidal products on $C$. estertheticum and C. gasigenes spores. All displayed sporicidal properties with treatment 2 (active ingredient sodium hypochlorite) being the most effective. This information, coupled with the D-values that suggest application times should be longer than the currently used 20 min, will inform more effective meat plant disinfection in the future.

Author Contributions: Conceptualization: D.B.; methodology: E.E. and L.K.; software: T.B.G. and P.W.; validation: D.B., T.B.G. and P.W.; formal analysis: E.E., L.K. and D.B.; investigation: E.E. and L.K.; resources: D.B., T.B.G. and P.W.; data curation: E.E. and L.K.; writing-original draft preparation: E.E. and L.K; writing-review \& editing: E.E., L.K., D.B., T.B.G. and P.W.; visualization: E.E., L.K., D.B., T.B.G. and P.W.; supervision: D.B., T.B.G. and P.W.; project administration: L.K. and D.B.; funding acquisition: D.B., T.B.G. and P.W. All authors have read and agreed to the published version of the manuscript. 
Funding: This work was funded by Meat Technology Ireland, a Technology Centre co-funded by Enterprise Ireland and a consortium of beef and sheep meat processors and the Teagasc Walsh Scholarship scheme in a collaborative project with AgResearch New Zealand.

Institutional Review Board Statement: Not applicable.

Informed Consent Statement: Not applicable.

Data Availability Statement: Not applicable.

Conflicts of Interest: The authors declare no conflict of interest.

\section{References}

1. Kalchayanand, N.; Ray, B.; Field, R.A.; Johnson, M.C. Spoilage of Vacuum-Packaged Refrigerated Beef by Clostridium. J. Food Prot. 1989, 52, 424-426. [CrossRef]

2. Broda, D.M. Psychrotrophic Clostridium spp. associated with 'blown pack' spoilage of chilled vacuum-packed red meats and dog rolls in gas-impermeable plastic casings. Int. J. Food Microbiol. 2002, 29, 335-352. [CrossRef]

3. Cavill, L.; Renteria-Monterrubio, A.L.; Helps, C.R.; Corry, J.E. Detection of cold-tolerant clostridia other than Clostridium estertheticum in raw vacuum-packed chill-stored meat. Food Microbiol. 2011, 28, 957-963. [CrossRef] [PubMed]

4. Broda, D.M.; De Lacy, K.M.; Cook, L.; Bell, G.R. Prevalence of cold-tolerant clostridia associated with vacuum-packed beef and lamb stored at abusive and chill temperatures. N. Z. J. Agric. Res. 1997, 40, 93-98. [CrossRef]

5. Broda, D.M.; Bell, R.G.; Boerema, J.A.; Musgrave, D.R. The abattoir source of culturable psychrophilic Clostridium spp. causing 'blown pack' spoilage of vacuum-packed chilled venison. J. Appl. Microbiol. 2002, 93, 817-824. [CrossRef]

6. Moschonas, G.; Bolton, D.J.; Sheridan, J.J.; McDowell, D.A. Isolation and sources of blown pack spoilage clostridia in beef abattoirs. J. Appl. Microbiol. 2009, 107, 616-624. [CrossRef]

7. Moschonas, G.; Bolton, D.J.; McDowell, D.A.; Sheridan, J.J. Diversity of culturable psychrophilic and psychrotrophic anaerobic bacteria isolated from beef abattoirs and their environments. Appl. Environ. Microbiol. 2011, 77, 4280-4284. [CrossRef]

8. Esteves, E.; Whyte, P.; Gupta, T.B.; Bolton, D.J. An investigation of the ecological niches and seasonal nature of Clostridium estertheticum and Clostridium gasigenes in the Irish beef farm environment. Lett. Appl. Microbiol. 2020, 71, 660-666. [CrossRef] [PubMed]

9. Maillard, J.-Y. Innate resistance to sporicides and potential failure to decontaminate. J. Hosp. Infect. 2011, 77, 204-209. [CrossRef]

10. Boerema, J.A.; Broda, D.M.; Penney, N.; Brightwell, G. Influence of Peryoxyacetic Acid-Based Carcass Rinse on the Onset of 'Blown Pack' Spoilage in Artificially Inoculated Vacuum-Packed Chilled Beef. J. Food Prot. 2007, 70, 1434-1439. [CrossRef]

11. Broda, D.M. The effect of peroxyacetic acid-based sanitizer, heat and ultrasonic waves on the survival of Clostridium estertheticum spores in vitro. Lett. Appl. Microbiol. 2007, 45, 336-341. [CrossRef] [PubMed]

12. Brightwell, G.; Clemens, R.; Adam, K.; Urlich, S.; Boerema, J. Comparison of culture-dependent and independent techniques for characterisation of the microflora of peryoxyacetic acid treated, vacuum-packaged beef. Food Microbiol. 2009, 26, $283-288$. [CrossRef] [PubMed]

13. Mills, J.; Horváth, K.M.; Brightwell, G. Antimicrobial effect of different peroxyacetic acid and hydrogen peroxide formats against spores of Clostridium estertheticum. Meat Sci. 2018, 143, 69-73. [CrossRef] [PubMed]

14. Russell, A.D. Bacterial Spores and Chemical Sporicidal Agents. Clin. Microbiol. Rev. 1990, 3, 99-119. [CrossRef]

15. Alasri, A.; Valverde, M.; Roques, C.; Michel, G.; Cabassud, C.; Aptel, P. Sporocidal properties of peracetic acid and hydrogen peroxide, alone and in combination, in comparison with chlorine and formaldehyde for ultrafiltration membrane disinfection. Can. J. Microbiol. 1993, 39, 52-60. [CrossRef]

16. Melly, E.; Cowan, A.E.; Setlow, P. Studies on the mechanism of killing of Bacillus subtilis spores by hydrogen peroxide. J. Appl. Microbiol. 2002, 93, 316-325. [CrossRef]

17. Leggett, M.J.; Schwarz, J.S.; Burke, P.A.; McDonnell, G.; Denyer, S.P.; Maillard, J.Y. Mechanism of Sporicidal Activity for the Synergistic Combination of Peracetic Acid and Hydrogen Peroxide. Appl. Environ. Microbiol. 2016, 82, 1035-1039. [CrossRef]

18. Sisti, M.; Brandi, G.; De Santi, M.; Rinaldi, L.; Schiavano, G.F. Disinfection efficacy of chlorine and peracetic acid alone or in combination against Aspergillus spp. and Candida albicans in drinking water. J. Water Health 2012, 10, 11-19. [CrossRef]

19. Straus, D.L.; Meinelt, T.; Farmer, B.D.; Mitchell, A.J. Peracetic acid is effective for controlling fungus on channel catfish eggs. J. Fish Dis. 2012, 35, 505-511. [CrossRef]

20. Zhang, C.; Brown, P.J.B.; Miles, R.J.; White, T.A.; Grant, D.G.; Stalla, D.; Hu, Z. Inhibition of regrowth of planktonic and biofilm bacteria after peracetic acid disinfection. Water Res. 2019, 149, 640-649. [CrossRef]

21. Middleton, A. Disinfection of bronchoscopes, contaminated in vitro with Mycobacterium tuberculosis, Mycobacterium aviumintracellulare and Mycobacterium chelonae in sputum, using stabilized, buffered peracetic acid solution ('Nu-Cidex'). J. Hosp. Infect. 1997, 37, 137-143. [CrossRef]

22. Marquis, R.; Rutherford, G.; Faraci, M.; Shin, S. Sporicidal action of peracetic acid and protective effects of transition metal ions. J. Ind. Microbiol. Biotechnol. 1995, 15, 486-492. [CrossRef] [PubMed]

23. André, S.; Hédin, S.; Remize, F.; Zuber, F. Evaluation of Peracetic Acid Sanitizers Efficiency against Spores Isolated from Spoiled Cans in Suspension and on Stainless Steel Surfaces. J. Food Prot. 2012, 75, 371-375. [CrossRef] [PubMed] 
24. Uwamahoro, M.; Massicotte, R.; Hurtubise, Y.; Gagné-Bourque, F.; Mafu, A.; Yahia, L. Evaluating the Sporicidal Activity of Disinfectants against Clostridium difficile and Bacillus amyloliquefaciens Spores by Using the Improved Methods Based on ASTM E2197-11. Front. Public Health 2018, 6, 18. [CrossRef] [PubMed]

25. Fatemi, P.; Frank, J.F. Inactivation of Listeria monocytogenes/Pseudomonas Biofilms by Peracid Sanitizers. J. Food Prot. 1999, 62, 761-765. [CrossRef] [PubMed]

26. Gram, L.; Bagge-Ravn, D.; Yin Ng, Y.; Gymoese, P.; Fonnesbech, B. Influence of food soiling matrix on cleaning and disinfection efficiency on surface attached Listeria monocytogenes. Food Control 2007, 18, 1165-1171. [CrossRef]

27. Ibusquiza, P.S.; Herrera, J.J.R.; Cabo, M.L. Resistance to benzalkonium chloride, peracetic acid and nisin during formation of mature biofilms by Listeria monocytogenes. Food Microbiol. 2011, 28, 418-425. [CrossRef]

28. Urano, H.; Fukuzaki, S. The mode of action of sodium hypochlorite in the cleaning process. Biocontrol Sci. 2005, 10, 21-29. [CrossRef]

29. Omidbakhsh, N. Evaluation of sporicidal activities of selected environmental surface disinfectants: Carrier tests with the spores of Clostridium difficile and its surrogates. Am. J. Infect. Control 2010, 38, 718-722. [CrossRef]

30. Hilgren, J.; Swanson, K.; Diez-Gonzalez, F.; Cords, B. Inactivation of Bacillus anthracis Spores by Liquid Biocides in the Presence of Food Residue. Appl. Environ. Microbiol. 2007, 73, 6370-6377. [CrossRef]

31. Xu, X.; Ran, Z.; Wen, G.; Liang, Z.; Wan, Q.; Chen, Z.; Lin, Y.; Li, K.; Wang, J.; Huang, T. Efficient inactivation of bacteria in ballast water by adding potassium peroxymonosulfate alone: Role of halide ions. Chemosphere 2020, 253, 126656. [CrossRef] [PubMed]

32. Zeng, F.; Cao, S.; Jin, W.; Zhou, X.; Ding, W.; Tu, R.; Han, S.; Wang, C.; Jiang, Q.; Huang, H.; et al. Inactivation of chlorine-resistant bacterial spores in drinking water using UV irradiation, UV/Hydrogen peroxide and UV/Peroxymonosulfate: Efficiency and mechanism. J. Clean. Prod. 2020, 243, 118666. [CrossRef]

33. Saklou, N.; Burgess, B.; Van Metre, D.; Hornig, K.; Morley, P.; Byers, S. Comparison of disinfectant efficacy when using highvolume directed mist application of accelerated hydrogen peroxide and peroxymonosulfate disinfectants in a large animal hospital. Equine Vet. J. 2015, 48, 485-489. [CrossRef]

34. Nerandzic, M.; Sunkesula, V.; Thriveen Sankar, C.; Setlow, P.; Donskey, C. Unlocking the Sporicidal Potential of Ethanol: Induced Sporicidal Activity of Ethanol against Clostridium difficile and Bacillus Spores under Altered Physical and Chemical Conditions. PLoS ONE 2015, 10, e0132805. [CrossRef]

35. Reid, R.; Bolton, D.; Tiuftin, A.A.; Kerry, J.P.; Fanning, S.; Whyte, P. Controlling Blown Pack Spoilage Using Anti-Microbial Packaging. Foods 2017, 6, 67. [CrossRef]

36. Reid, R.; Burgess, C.M.; McCabe, E.; Fanning, S.; Whyte, P.; Kerry, J.; Bolton, D. Real-time PCR methods for the detection of blown pack spoilage causing Clostridium species; C. estertheticum, C. gasigenes and C. ruminantium. Meat Sci. 2017, 133, 56-60. [CrossRef]

37. Jamroskovic, J.; Chromikova, Z.; List, C.; Bartova, B.; Barak, I.; Bernier-Latmani, R. Variability in DPA and Calcium Content in the Spores of Clostridium Species. Front. Microbiol. 2016, 7, 1791. [CrossRef] [PubMed]

38. Rajagopal, S.; McMullen, L.M.; Gill, C.O.; Yang, X. Characterization of germination of spores of Clostridium estertheticum, the primary causative agent of blown pack spoilage of vacuum packaged beef. Food Res. Int. 2016, 87, 109-114. [CrossRef]

39. Boerema, J.A.; Broda, D.M.; Bell, R.G. Abattoir sources of psychrophilic clostridia causing blown pack spoilage of vacuum-packed chilled meats determined by culture-based and molecular detection procedures. Lett. Appl. Microbiol. 2003, 36, 406-411. [CrossRef]

40. Bolton, D.J.; Carroll, J.; Walsh, D. A four-year survey of blown pack spoilage Clostridium estertheticum and Clostridium gasigenes on beef primal cuts. Lett. Appl. Microbiol. 2015, 61, 153-157. [CrossRef]

41. McSharry, S.; Koolman, L.; Whyte, P.; Bolton, D. Investigation of the Effectiveness of Disinfectants Used in Meat-Processing Facilities to Control Clostridium sporogenes and Clostridioides difficile Spores. Foods 2021, 10, 1436. [CrossRef] [PubMed]

42. Finnegan, M.; Linley, E.; Denyer, S.P.; McDonnell, G.; Simons, C.; Maillard, J.Y. Mode of action of hydrogen peroxide and other oxidizing agents: Differences between liquid and gas forms. J. Antimicrob. Chemother. 2010, 65, 2108-2115. [CrossRef]

43. Blakistone, B.; Chuyate, R.; Kautter, D., Jr.; Charbonneau, J.; Suit, K. Efficacy of Oxonia Active Against Selected Spore Formers. J. Food Prot. 1999, 62, 262-267. [CrossRef] [PubMed]

44. Shetty, N.; Srinivasan, S.; Holton, J.; Ridgway, G.L. Evaluation of microbicidal activity of a new disinfectant: Sterilox ${ }^{\circledR} 2500$ against Clostridium difficile spores, Helicobacter pylori, vancomycin resistant Enterococcus species, Candida albicans and several Mycobacterium species. J. Hosp. Infect. 1999, 41, 101-105. [CrossRef]

45. Dawson, L.F.; Valiente, E.; Donahue, E.H.; Birchenough, G.; Wren, B.W. Hypervirulent Clostridium difficile PCR-Ribotypes Exhibit Resistance to Widely Used Disinfectants. PLoS ONE 2011, 6, e25754. [CrossRef]

46. Cho, W.-I.; Chung, M.-S. Sporicidal activities and mechanism of surfactant components against Clostridium sporogenes spores. J. Food Sci. Technol. 2018, 55, 4675-4680. [CrossRef]

47. Harrison, J.; Hand, R. The effect of dilution and organic matter on the antibacterial property of 5.25\% sodium hypochlorite. $J$. Endod. 1981, 7, 128-132. [CrossRef]

48. Ulrich, J. Antimicrobial Efficacy in the Presence of Organic Matter. In Skin Microbiology; Springer: New York, NY, USA, 1981; pp. 149-157. [CrossRef]

49. Lourenço, C.; Macdonald, T.J.; Gavriilidis, A.; Allan, E.; MacRobert, A.J.; Parkin, I.P. Effects of bovine serum albumin on light activated antimicrobial surfaces. RSC Adv. 2018, 8, 34252-34258. [CrossRef] 
50. Kunanusont, N.; Punyadarsaniya, D.; Jantafong, T.; Pojprasath, T.; Takehara, K.; Ruenphet, S. Bactericidal efficacy of potassium peroxymonosul fate under various concentrations, organic material conditions, exposure timing and its application on various surface carriers. J. Vet. Med. Sci. 2020, 82, 320-324. [CrossRef]

51. Korukluoglu, M.; Sahan, Y.; Yigit, A. The fungicidal efficacy of various commercial disinfectants used in the food industry. Ann. Microbiol. 2006, 56, 325. [CrossRef]

52. Hasan, T.; Ali Kadhum, H.; Alasedi, K. The Using of Ethanol and Isopropyl Alcohol as a disinfectant: Review. Int. J. Pharm. Res. 2020, 13, 2150-2152. [CrossRef]

53. Sanderson, H.; van Compernolle, R.; Dyer, S.; Price, B.; Nielsen, A.; Selby, M.; Ferrer, D.; Stanton, K. Occurrence and risk screening of alcohol ethoxylate surfactants in three U.S. river sediments associated with wastewater treatment plants. Sci. Total Environ. 2013, 463-464, 600-610. [CrossRef] [PubMed]

54. Arias-Moliz, M.; Ferrer-Luque, C.; Espigares-Rodríguez, E.; Liébana-Ureña, J.; Espigares-García, M. Bactericidal activity of phosphoric acid, citric acid, and EDTA solutions against Enterococcus faecalis. Oral Surg. Oral Med. Oral Pathol. Oral Radiol. Endod. 2008, 106, e84-e89. [CrossRef]

55. Scott, B.; Yang, X.; Geornaras, I.; Delmore, R.; Woerner, D.; Reagan, J.; Morgan, J.; Belk, K. Antimicrobial Efficacy of a Sulfuric Acid and Sodium Sulfate Blend, Peroxyacetic Acid, and Cetylpyridinium Chloride against Salmonella on Inoculated Chicken Wings. J. Food Prot. 2015, 78, 1967-1972. [CrossRef]

56. Prada, I.; Micó-Muñoz, P.; Giner-Lluesma, T.; Micó-Martínez, P.; Muwaquet-Rodríguez, S.; Albero-Monteagudo, A. Update of the therapeutic planning of irrigation and intracanal medication in root canal treatment. A literature review. J. Clin. Exp. Dent. 2019, 11, e185-e193. [CrossRef] [PubMed]

57. McDonnell, G.; Russell, A. Antiseptics and Disinfectants: Activity, Action, and Resistance. Clin. Microbiol. Rev. 1999, 12, 147-179. [CrossRef]

58. Ruano, M.; El-Attrache, J.; Villegas, P. Efficacy Comparisons of Disinfectants Used by the Commercial Poultry Industry. Avian Dis. 2001, 45, 972. [CrossRef]

59. Tennen, R.; Setlow, B.; Davis, K.; Loshon, C.; Setlow, P. Mechanisms of killing of spores of Bacillus subtilis by iodine, glutaraldehyde and nitrous acid. J. Appl. Microbiol. 2000, 89, 330-338. [CrossRef]

60. Pennell, K.; Naunovic, Z.; Blatchley, E. Sequential Inactivation of Bacillus Subtilis Spores with Ultraviolet Radiation and Iodine. J. Environ. Eng. 2008, 134, 513-520. [CrossRef]

61. Setlow, P. Spore germination. Curr. Opin. Microbiol. 2003, 6, 550-556. [CrossRef]

62. Huang, S.S.; Chen, D.; Pelczar, P.L.; Vepachedu, V.R.; Setlow, P.; Li, Y.Q. Levels of Ca ${ }^{2+}$-Dipicolinic Acid in Individual Bacillus Spores Determined Using Microfluidic Raman Tweezers. J. Bacteriol. 2007, 189, 4681-4687. [CrossRef] [PubMed]

63. Leggett, M.J.; McDonnell, G.; Denyer, S.P.; Setlow, P.; Maillard, J.Y. Bacterial spore structures and their protective role in biocide resistance. J. Appl. Microbiol. 2012, 113, 485-498. [CrossRef] [PubMed] 